\title{
Chinese scientists to get Western form of recognition
}

London. Chinese science has moved further towards remoulding itself along Western lines with a decision to designate the members of the scientific council of the Chinese Academy of Sciences as "academicians".

The academy has also announced its first 10 foreign academicians, including the eminent British historian of Chinese science, Joseph Needham. And a companion body has been set up, the Chinese Academy of Engineering, as a focal point for the development of new technologies.

The science academy's scientific council is China's leading science and technology advisory body.

In the past, China has formally eschewed the élitism implicit in Western scientific institutions by refusing to give any extra recognition to members of the council.

According to academy officials, the reason for granting council members the title of academician is to facilitate international exchanges and express the "authoritative and honorary status" of the council. A similar system will be introduced for the engineering academy.

Speaking at a meeting of both bodies in Beijing earlier this month, the Chinese premier, Li Peng, described the move as "an important measure which conforms to the practice of the sci- UNAVAILABLE entific and technological communities of the world, as well as the strong and general aspirations of the scientific and techno-

logical communities at home".

$\mathrm{He}$ also said that the founding of the engineering academy is a major event for China's engineering communities and an important part of the country's drive for modernization. The appointment of the foreign academicians would have a "positive impact on opening China's scientific and technological field wider to the outside world", he added.

David Foster of Britain's Royal Society said that the society welcomed the decision to describe the scientific council members as academicians. It gave "a clear indication of the desire of the Chinese government to continue to accord scientists and engineering a high status which matches that of their counterparts in other countries".

$\mathrm{He}$ also described the decision to elect the first foreign academicians as "a landmark in the history of scientific links between China and the rest of the world".

\section{Deaths bring clinical trials under scrutiny in Japan}

Tokyo. Deficiencies in Japan's procedures for monitoring and assessing clinical trials have been brought to light by a rapidly developing scandal over a new antiviral drug that has killed several patients, both during trials and after receiving government approval.

In the latest twist in the scandal, the Securities and Exchange Surveillance Commission (SESC) last week raided the head office of Nippon Shoji Kaisha, the company that developed the drug Sorivudine, on suspicion that employees have been engaged in insider trading.

The SESC's action was prompted by the fact that the employees sold shares they held in the company shortly before a government announcement on 12 October 1993 that several patients had died after using the drug in combination with anticancer agents.

After several years of clinical trials starting in 1985, Sorivudine, which contains an arabinofuranosyl uracil derivative as its active ingredient, was approved by the government last July for treatment of shingles, the adult form of chicken pox caused by the virus herpes zoster.

The drug went on the market on 3 September. But within days, several deaths were reported in cancer patients being treated for shingles when the drug was used in combination with fluorouracil anticancer drugs.

The company suspended shipments of the drug on 12 October, after the government had announced the first deaths. But by November, 15 deaths, and numerous cases of serious side-effects, had been reported.

Two weeks ago, Asahi Shimbun, one of Japan's leading business newspapers, revealed that three people had died during clinical trials when the drug was used in combination with anticancer agents. But the company reported only one death to the Ministry of Health and Welfare when it submitted the drug for licensing approval.

Sorivudine is thought to act with fluorouracil to inhibit the anticancer agent's breakdown in the body, making it more toxic. Sorivudine carried a warning that it should not be used in combination with anticancer agents. But the warning did not specify that death could result.

Masanori Fukushima of Aichi Cancer Centre, who has been campaigning for the revision of Japan's clinical trial system (see Nature 342,$850 ; 1989$ ) describes the Sorivudine case as "shameful", but says it is "by no means an exception". He and other critics point out several defects in the clinical trials of the drug.

For example, reports on the trials were published in Japanese only in local journals, and the quality of many of the papers in these publications is "very poor", says Fukushima. The abstract of the paper on the phase III clinical trial makes no mention of the number of patients, or of the side-effects (including death) that occurred.

More serious are the accusations that some of those who carried out the clinical trials should have been aware of the drug's potentially dangerous interaction with anticancer agents. Animal studies in Belgium, Japan and the Netherlands published in 1986 and 1987 indicated that the drug bromovinyldeoxyuracil (BVDU), which has a similar structure to Sorivudine, increases the toxicity of fluorouracil anticancer drugs.

M. Niimura of Jikei University School of Medicine, who supervised the Sorivudine clinical trials, is reported in Asahi Shimbun as saying that he read the Belgian BVDU study, but failed to link it to deaths in the early stages of the Sorivudine clinical trials.

Fukushima claims that a basic problem is the lack of good education in clinical pharmacology in Japanese medical schools.

A thorough investigation is still awaited of the reasons why the government's approval process failed to pick up the dangers of Sorivudine. One reason, says Fukushima, is inadequate expertise in the ministry's drug approval committee.

Another reason, he suggests, is the lack of an adequate independent system for inspecting clinical trials. In the United States the Food and Drug Administration has more than a hundred inspectors to check the conduct of such trials; Japan has only two.

David Swinbanks

\section{Malaysia to boost pay for foreign scientists}

London. The Malaysian government is drawing up proposals to offer Western salaries to foreign scientists and engineers to attract them to work in the country. The offer, which is expected to form a key element of the government's plans to become a fully industrialized nation by the year 2020 , will also be open to Malaysian scientists and engineers currently working abroad.

According to the Bernama News Agency in Kuala Lumpur, a paper drawn up by a working party from the ministry of science, technology and the environment setting out the details of this plan are currently awaiting the approval of various other government departments, including the Treasury. If the endorsement of these agencies is received, the plan will be submitted to the cabinet for final approval. 